\title{
PENYEBAB KESALAHAN KOHESI LEKSIKAL DAN GRMATIKAL DALAM KARANGAN EKSPOSISI SISWA
}

\author{
Ria Anggari Putri', Miftahulkhairah Anwar², Siti Ansoriyah ${ }^{3}$ \\ Program Studi Pendidikan Bahasa, Pascasarjana, Universitas Negeri Jakarta \\ ${ }^{1}$ riaanggariputri_pb16s2mahasiswa.unj.ac.id, ${ }^{2}$ miftahulkhairah@unj.ac.id, \\ siti.ansoriyah@unj.ac.id
}

\begin{abstract}
Abstrak
Penelitian ini bertujuan untuk mengidentifikasikan dan mendeskripsikan penyebab kesalahan berbahasa yang terdapat dalam karangan eksposisi siswa. Teori yang digunakan dalam penelitian ini adalah teori kesalahan berbahasa, yaitu kesalahan yang dideskripsikan berdasarkan faktor penyebab yang ditemukan dari kesalahan tersebut. Selain itu, beberapa konsep mengenai wacana juga digunakan sebagai landasan teori dalam penelitian ini. Penelitian ini dilaksanakan pada semester genap tahun pelajaran 2017/2018. Data penelitian berupa karangan eksposisi siswa kelas $\mathrm{X}$. Hasil penelitian menunjukkan bahwa kesalahan berbahasa terjadi karena adanya faktor penyebab. Faktor penyebab tersebut meliputi faktor kompetensi dan performansi. Adapun dari segi performansi, faktor yang paling banyak ditemukan yaitu karena kurangnya konsentrasi siswa. Banyak siswa yang merasa sulit berkonsentrasi saat pembelajaran menulis karangan eksposisi dan sulit konsentrasi tersebut sebenarnya juga dipengaruhi oleh beberapa faktor lainnya. Adapun dari segi faktor kompetensi yaitu kurangnya pengetahuan siswa terhadap kaidah-kaidah di dalam bahasa sehingga siswa menjadi bingung dalam menerapkan kaidah yang benar di dalam karangan eksposisi.
\end{abstract}

Kata Kunci: kesalahan berbahasa, faktor kompetensi, faktor performansi

\begin{abstract}
This study aims to identify and describe the causes of language errors contained in students' exposition essays. The theory used in this study is the theory of language errors, namely errors that are described based on the causal factors found from these errors. In addition, several concepts regarding discourse are also used as the theoretical basis in this study. This research was conducted in the even semester of the academic year 2017/2018. The research data was in the form of expositions of class $X$ students. The results of the study showed that language errors occur because of the causal factors. The causes include competency and performance factors. As for performance, the most common factor is the lack of concentration of students. Many students find it difficult to concentrate while learning to write exposition essays and difficult concentration is actually also influenced by several other factors. In terms of competency factors, it is the lack of students' knowledge of the rules in language so that students become confused in applying the correct rules in the exposition essay.
\end{abstract}

Keywords: language errors, competency factors, performance factors. 


\section{PENDAHULUAN}

Pembelajaran bahasa merupakan salah satu aspek dalam menunjang dunia pendidikan. Dalam hal ini, peranan bahasa dijadikan sebagai sarana dalam proses pembelajaran bahasa. Pembelajaran bahasa berkaitan erat dengan proses berpikir yang mendasari bahasa. Proses berpikir yang mengaitkan beberapa keterampilan berbahasa meliputi keterampilan berbicara, menyimak, membaca, dan menulis.

Dari keempat keterampilan tersebut, menulis merupakan salah satu keterampilan yang memiliki keterkaitan dalam proses berpikir siswa. Hal tersebut dapat dilihat dari hasil tulisan yang mereka buat. Dalam hal ini, kohesi menjadi modal utama untuk dijadikan sebagai acuan dalam menulis siswa. Dengan dibantu oleh kohesi maka tulisan siswa pun menjadi lebih padu.

Senada dengan hal tersebut, pada dasarnya pembelajaran bahasa, terutama bahasa Indonesia bertujuan untuk membekali peserta didik agar memiliki kemampuan berkomunikasi secara efektif dan efisien dalam berbahasa lisan dan tulisan. Hal ini dikarenakan perubahan atau pergantian kurikulum yang terjadi selalu menimbulkan masalah serta membingungkan semua yang terlibat dalam kegiatan pendidikan, terutama guru. Apapun jenis kurikulumnya, guru bahasa Indonesia harus tetap berpegang pada tujuan pembelajaran bahasa Indonesia. Guru harus terus berusaha untuk meningkatkan kemampuannya dan terus belajar untuk memberikan yang terbaik bagi peserta didiknya (Wiyanti, 2016).

Menulis merupakan salah satu keterampilan berbahasa yang harus dikuasai oleh siswa dalam proses pembelajaran, untuk itu pembelajaran menulis telah ditanamkan sejak dini dari kurikulum Sekolah Dasar sampai pendidikan menengah atas dalam setiap pembelajaran bahasa. Salah satunya dalam pembelajaran bahasa Indonesia. Namun, kenyataan yang ada dalam setiap pembelajaran menulis terutama dalam bahasa Indonesia, peserta didik masih banyak yang melakukan kesalahan pada hasil kegiatan menulis atau mengarangnya. Berdasarkan hasil wawancara dengan salah satu guru bahasa Indonesia di SMAN 4 Tambun Selatan, disampaikan bahwa hasil dari tulisan siswa masih ditemui tulisan yang tidak utuh terhadap ide yang disampaikan sehingga sulit dipahami ide atau gagasan yang ada di dalamnya. Tidak hanya itu, peserta didik juga kesulitan dalam merangkai kata dan menuangkannya ke dalam sebuah tulisan sehingga kalimat yang dibuatnya pun masih tidak utuh secara keseluruhan. Hal tersebut membuat tulisan yang dibuat oleh siswa menjadi sulit dipahami bagi para pembaca (Azzahra, 2017).

Terkait dengan kesalahan penggunaan kohesi yang terdapat di dalam karangan siswa. Dalam hal ini, menunjukkan bahwa kesalahan berbahasa tidak hanya terdapat pada tuturan (bahasa lisan), melainkan juga terdapat pada tulisan (bahasa tulis). Pada bahasa tulis, unsur-unsur bahasa yang digunakan haruslah lengkap. Menurut (Sako, 2017) apabila unsur-unsur bahasa yang digunakan tidak lengkap, maka informasi yang disampaikan pun tidak dapat dipahami secara tepat atau disebut sebagai kesalahan bahasa tertulis. Semua unsur bahasa yang ada hendaknya digunakan dengan tepat dan efektif serta disesuaikan dengan tujuan, isi, dan latar belakang pembaca.

Di sisi lain, supaya teks dapat dipahami oleh pembaca maka wacananya pun harus padu, baik dari segi leksikalnya maupun gramatikalnya. Namun, karangan eksposisi siswa-siswi di SMAN 4 Tambun Selatan masih banyak ditemui wacana yang tidak utuh dan pertautan antar kalimatnya tidak saling terkait sehingga informasi yang dituliskan menjadi tidak jelas. Paragraf demi paragrafnya pun hanya sekadar kumpulan kalimat dan tidak saling membentuk makna secara kesatuan. Hal itulah yang membuat karangan 
siswa masih perlu diberi tindakan lebih lanjut oleh guru bahasa Indonesia yang bersangkutan.

Adapun menurut (Djajasudarma, 2006) apapun bentuknya, wacana mengasumsikan adanya penyapa (addressor) dan pesapa (addressee). Dalam wacana lisan, penyapa adalah pembicara sedangkan pesapa adalah pendengar, sedangkan dalam wacana tulis, penyapa adalah penulis sedangkan pesapa adalah pembaca. Dalam hal ini, pemahaman wacana lebih menitikberatkan pada hasil yaitu hasil dari rekaman kebahasaan yang utuh dalam peristiwa komunikasi baik dalam wujud lisan maupun tulisan.

Senada dengan hal tersebut, hubungan antarunsur yang membentuk wacana adalah apa yang disebut sebagai rentetan kalimat yang berkaitan sehingga terbentuklah makna yang serasi di antara kalimat-kalimat tersebut atau wacana juga dapat didefinisikan sebagai rentetan kalimat yang berkaitan yang menghubungkan proposisi yang satu dengan proposisi yang lain dan membentuk satu kesatuan. Wacana ini direalisasikan dalam bentuk karangan yang utuh seperti novel, buku, seri ensiklopedia, dan sebagainya yang membawa amanat lengkap. Dijelaskan pula bahwa wujud wacana dapat dilihat dari segi tataran bahasa, dimulai dari tataran terkecil yaitu "kata" yang dapat membuat makna utuh apabila dilihat dari informasi yang mendukungnya (Djajasudarma, 2006).

Bila dilihat lebih lanjut, kohesi merupakan keserasian hubungan antara unsur yang satu dengan unsur yang lain dalam wacana sehingga tercipta pengertian yang apik atau koheren. Selain itu, penentu utama untuk menentukan apakah seperangkat kalimat itu merupakan suatu teks, maka sangat bergantung pada hubungan-hubungan kohesif yang ada di dalam dan di antara kalimat-kalimat itu, serta dapat membentuk suatu jaringan atau tekstur (texture). Dengan demikian, profil wacana yang kohesif ditunjukkan oleh penanda formal yang menghubungkan apa yang telah dikatakan dengan apa yang segera akan dikatakan (Moeliono, 2010).

Di sisi lain, kohesi pun juga dianggap berada di luar struktur teks karena struktur dalam teks disediakan oleh tata bahasa. Dengan kata lain, desain kohesi dalam teks terhubung ke dalam ikatan semantik atau hubungan makna yang ada di dalam teks (Michael, 2013). Melihat keterkaitan antara wacana dan kohesi, menjadi jelas bahwa hubungan kohesi terbentuk jika penafsiran suatu unsur dalam ujaran bergantung pada penafsiran makna ujaran yang lain, dengan arti bahwa yang satu tidak akan dapat ditafsirkan maknanya dengan efektif, kecuali dengan mengacu kepada unsur yang lain (Setiawati, 2016). Senada pula dengan pendapat yang diungkapkan oleh Nordquist dalam penelitian yang dilakukan oleh Digna Palupi yang memberi penegasan tentang paragraf bahwa kunci kualitas sebuah paragraf yang efektif adalah adanya kesatuan.

Kalimat-kalimat dalam paragraf berkontribusi terhadap tujuan serta gagasan utama dari awal sampai akhir paragraf sehingga pembaca mudah memahami isi paragraf. Dari pendapat tersebut maka dapat dikatakan bahwa wacana yang padu adalah wacana yang isinya memiliki satu topik dan menunjukkan kohesif dan koheren sehingga mudah dipahami oleh pembaca (Palupi, 2013).

Terkait dengan kekohesifan wacana, dalam hal ini karangan siswa masih banyak yang perlu diperbaiki karena ketidakpaduan yang ditemukan juga berkaitan erat dengan kesalahan berbahasa. Pada pembelajaran menulis di sekolah, siswa seringkali kurang mendapatkan perhatian dari guru. Hal ini dibuktikan dengan minimnya kompetensi menulis siswa dalam kurikulum 2013 pada tingkat SMA. Padahal dalam pembelajaran menulis memiliki fungsi yang sangat positif bagi siswa. Fungsi tersebut adalah untuk mengasah ketajaman berpikir dan melatih cara berpikir kreatif siswa. Pada dasarnya 
adanya kesalahan dalam pembelajaran bahasa yang dilakukan oleh siswa, bukan merupakan hal yang aneh sebab pembelajaran dan kesalahan tidak dapat terpisahkan.

Karangan eksposisi merupakan karangan yang bersifat memaparkan, memberitahukan ataupun menjelaskan sesuatu secara informal, apa adanya dan tidak memaksa pembaca untuk menerima atau menolak dari isi paparan yang disampaikan oleh penulis. Oleh karena itu, eksposisi biasanya disajikan dengan bahasa denotatif dan rasional. Tujuannya adalah untuk menambah pengetahuan dan bukan untuk menimbulkan imajinasi bagi pembaca. Selain itu, eksposisi juga memberikan pengetahuan atau informasi mengenai suatu peristiwa. Berkaitan dengan hal tersebut, eksposisi dapat berupa ilustrasi yang disertai contoh, identifikasi, komparasi atau uraian yang kronologis demi tercapainya pemahaman yang baik mengenai isi wacana tersebut (Arifin dkk., 2015).

Melihat dari berbagai konsep yang telah disebutkan, maka penelitian terhadap karangan siswa ini merupakan penelitian kesalahan berbahasa dengan dasar teori wacana. Adapun alasan dipilihnya karangan eksposisi siswa karena muatan isinya yang beragam dari setiap siswa. Siswa tersebutlah yang langsung mengembangkan proses kreativitasnya melalui tulisan. Selain itu, karangan eksposisi dipilih karena gagasan demi gagasannya lebih tersusun dari hal yang umum ke hal yang khusus ataupun sebaliknya sehingga lebih sistematis. Begitu pula dengan pola strukturnya yang lebih terkonsep sehingga peneliti akan lebih mudah untuk mengaitkan kepaduan antara kalimat yang satu dengan yang lainnya.

Senada dengan karangan eksposisi yang dipilih, alasan peneliti memfokuskan penelitian terhadap kesalahan berbahasa pada tataran sintaksis karena melalui observasi awal pada pemahaman dan penguasaan struktur bahasa khususnya pemilihan kata (diksi), frasa, klausa dan kalimat dalam bahasa tulis yang dimiliki siswa, rata-rata masih belum benar. Dari hasil pemaparan tersebut menunjukkan bahwa hasil pembelajaran menulis terutama yang terkait dengan aspek kewacanaan sampai saat ini masih memprihatinkan. Namun, bukan berarti jika siswa tidak memiliki kemampuan menulis yang tidak dapat dioptimalkan.

Oleh karena itu, untuk mengoptimalkan kemampuan menulis siswa, perlu diketahui lebih dulu kesalahan-kesalahan yang sering dibuat siswa. Salah satu kesalahan yang sering dibuat siswa dalam menulis adalah kesalahan dalam menggunakan peranti kohesi. Lebih lanjut, dari kesalahan dan ketidakpaduan tersebut akan mudah untuk diidentifikasi dari penyebab kesalahannya. Berdasarkan hal-hal yang telah diuraikan sebelumnya, maka peneliti tertarik untuk mendeskripsikan penyebab dari kesalahan kohesi yang dibuat oleh siswa. Masalah yang dikaji dalam penelitian ini adalah bagaimana penyebab kesalahan berbahasa yang terdapat dalam karangan eksposisi siswa?

Tujuannya adalah mengidentifikasikan dan mendeskripsikan penyebab kesalahan berbahasa yang terdapat dalam karangan eksposisi siswa. Penelitian ini diharapkan dapat bermanfaat sebagai salah satu dokumentasi yang mampu serta menjadi acuan dalam berbagai kajian mengenai kesalahan berbahasa dalam karangan siswa oleh akademisi dan masyarakat umum secara keseluruhan.

\section{Kesalahan Berbahasa}

Menurut (James, 1998), kesalahan berbahasa adalah penyimpangan yang dilakukan tanpa disengaja dan kesalahan tersebut tidak dapat diperbaiki oleh penutur itu sendiri, hal tersebut terjadi karena ketidaktahuannya. 
Adapun analisis kesalahan berbahasa menurut Samsuri dalam (Bueraheng, 2017) merupakan kegiatan pengkajian dari segala aspek penyimpangan berbahasa itu sendiri. Analisis kesalahan berbahasa sangat diperlukan untuk mengetahui bagaimana bahasa diucapkan, ditulis, disusun, dan berfungsi.

Richard (1974) pun mendefinisikan bahwa kesalahan berbahasa merupakan bentuk penyimpangan norma yang terdapat di dalam ujaran sebagai akibat dari kedekatan dengan bahasa pertamanya. Selain itu, kesalahan merupakan sisi yang mempunyai cacat pada ujaran atau tulisan pada diri pelajar. Kesalahan tersebut merupakan bagian konversasi atau komposisi yang menyimpang dari norma baku atau norma terpilih dari performansi bahasa orang dewasa (Tarigan, 1988).

Di sisi lain, menurut Jain dalam (Tarigan, Pengajaran Analisis Kesalahan Berbahasa, 1988), kesalahan berbahasa ada yang tidak dilatarbelakangi oleh bahasa pertama atau B1 seperti kesalahan perkembangan dan kesalahan karena penyamarataan atau generalisasi. Dalam bahasa Inggris, kesalahan berbahasa yang tidak dilatarbelakangi oleh bahasa B1 siswa dikenal dengan istilah "L1 independent errors". Kesalahan tersebut disebabkan oleh berbagai faktor antara lain strategi belajar, teknik pengajaran, folklore bahasa kedua, usia kedwibahasaan dan situasi sosiolinguistik siswa. Dalam hal ini, analisis kesalahan berbahasa lebih menekankan pada aspek kreatif siswa pelajar bahasa serta menempatkan siswa sebagai titik pusat pembelajaran bahasa dan pembelajaran B2 dibandingkan dengan anakon yang menekankan peran guru sebagai titik pusatnya (Parera, 1997).

\section{Faktor Kesalahan Berbahasa}

Kesalahan berbahasa atau language errors memiliki jenis yang beraneka ragam serta dapat dikelompokkan dengan berbagai cara sesuai dengan perspektif pandangan masingmasing. Selanjutnya (Tarigan, 1988) yang membedakannya atas dua jenis, yaitu:

1. Kesalahan yang disebabkan oleh faktor kelelahan, keletihan dan kurangnya perhatian disebut sebagai faktor performansi, kesalahan performansi inilah yang merupakan bentuk kesalahan penampilan dan dalam beberapa kepustakaan disebut "mistakes".

2. Kesalahan yang diakibatkan oleh kurangnya pengetahuan mengenai kaidah-kaidah bahasa disebut sebagai faktor kompetensi. Faktor kompetensi merupakan penyimpangan-penyimpangan sistematis yang disebabkan oleh pengetahuan pelajar atau siswa yang sedang berkembang mengenai sistem B2 (atau bahasa kedua) yang disebut sebagai "errors" (Tarigan, 1988).

Adapun menurut Richard (1974), analisis kesalahan dilakukan untuk mengidentifikasi strategi yang digunakan oleh pembelajar, mengidentifikasi penyebab dari kesalahan dan memperoleh informasi tentang kesulitan yang bisa dijumpai dalam proses belajar bahasa sebagai alat bantu dalam mempersiapkan bahan ajar. Dalam hal ini, Jack Richard menjabarkan sumber kesalahan berbahasa yang terdiri dari :

1. Penerapan kaidah secara tidak lengkap.

Pembelajar cenderung tidak lengkap menerapkan kaidah apabila suatu ketika pembelajar menerapkan kaidah secara berlebihan. Pada umumnya, hal tersebut disebabkan untuk menghindari beban linguistik yang terlalu besar.

2. Generalisasi berlebih

Generalisasi berlebih yaitu fakta dan kebiasaan dari pembelajar bahasa untuk membuat bentuk-bentuk kesalahan yang sama, yang diketahui oleh pembelajar dan dalam bahasa yang sedang dipelajarinya. Semua kaidah bahasa tersebut disamaratakan oleh pembelajar bahasa. 
3. Ketidaktahuan akan batas-batas aturan suatu bahasa.

Jenis kesalahan ini hampir sama dengan kesalahan dalam tindak generalisasi. Perbedaannya adalah keduanya bertolak dari ketidaktahuan, sedangkan generalisasi lebih disebabkan oleh perasaan serba tahu dalam menempatkan suatu aturan bahasa.

4. Kesalahan konsep.

Kesalahan konsep merupakan kesalahan yang muncul sebagai hasil dari perbedaan komprehensif dalam bahasa yang sedang dipelajari pembelajar. Selain itu, kadangkadang juga terjadi karena perbedaan tingkatan materi pengajaran yang diajarkan di sekolah (Richard, 1974)

\section{Hakikat Wacana}

Saat ini, bahasa tidak lagi dipandang sebagai alat komunikasi yang diperinci dalam bentuk bunyi, frasa, ataupun kalimatnya secara terpisah-pisah. Setiap orang menggunakan bahasa dalam wujud kalimat yang saling berkaitan. Kalimat yang pertama menyebabkan timbulnya kalimat yang kedua, kalimat kedua menjadi acuan untuk kalimat ketiga, kalimat ketiga mengacu kembali ke kalimat pertama, dan seterusnya. Rentetan kalimat yang berkaitan yang menghubungkan proposisi yang satu dengan proposisi yang lain dan membentuk kesatuan dinamakan wacana (Moeliono, 2010).

Di sisi lain, (Kurniasari, 2017) mengungkapkan bahwa kalimat sebagai bagian dari wacana memerlukan penanda kohesi yang tidak hanya sebagai alat penghubung unit struktur, tetapi juga berfungsi semantis. Oleh karena itu, penanda kohesi tidak hanya berhubungan dengan bentuk (kohesi gramatikal) tetapi juga berhubungan dengan makna (kohesi leksikal). Selain itu, wacana yang kohesif akan membawa pengaruh kejelasan hubungan antara satuan bentuk yang satu dengan yang lain sehingga pesan yang ingin disampaikan menjadi jelas dan utuh.

\section{Jenis-Jenis Wacana}

Di dalam komunikasi terdapat berbagai jenis wacana. Wacana dapat diklasifikasikan berdasarkan beberapa jenis. Berikut ini dijelaskan secara singkat mengenai klasifikasi wacana. Wacana dapat diklasifikasikan berdasarkan atas wacana ekspresif yaitu apabila wacana tersebut bersumber pada gagasan penutur atau penulis sebagai sarana ekspresi, seperti wacana pidato. Selanjutnya yaitu wacana fatis, apabila wacana itu bersumber pada saluran untuk memperlancar komunikasi, seperti wacana perkenalan dalam pesta. Berikutnya yaitu wacana informasional, apabila wacana itu bersumber pada pesan atau informasi, seperti wacana berita dalam media masa. Kemudian, wacana estetik yaitu apabila wacana itu bersumber pada pesan dengan tekanan keindahan pesan, seperti wacana puisi dan lagu.

Yang terakhir wacana direktif, yaitu apabila wacana itu diarahkan pada tindakan atau reaksi dari mitra tutur atau pembaca, seperti wacana khutbah (Kushartanti, 2009). Selain itu, wacana juga dibedakan berdasarkan saluran komunikasi, yang terdiri atas wacana lisan dan wacana tulis. Wacana lisan memiliki ciri antara lain adanya penutur dan mitra tutur, bahasa yang dituturkan, dan alih tutur (turn taking) yang menadai pergantian giliran bicara. Selain itu, wacana tulis ditandai adanya penulis dan pembaca, bahasa yang dituliskan, dan penerapan sistem ejaan.

Berdasarkan pemaparan, secara umum wacana juga dikelompokkan atas wacana naratif, wacana deskriptif, wacana ekspositoris, wacana argumentatif, wacana persuasif, wacana hortatoris dan wacana prosedural. Wacana naratif dicirikan oleh adanya alur, peristiwa, dan tokoh, seperti pada narasi faktual (contohnya berita) dan narasi fiktif 
(cerpen, novel). Selanjutnya yaitu wacana deskriptif yang dicirikan oleh adanya detail suatu hal seperti pada profil. Berikutnya wacana ekspositoris yang dicirikan oleh kuatnya paparan informasi seperti pada karangan khas (future). Selanjutnya, wacana argumentatif dicirikan oleh kuatnya argumentasi karena didukung oleh ekplorasi bukti dan prosedur metodologis, seperti pada tesis dan disertasi.

Berikutnya, yaitu wacana persuasif yang dicirikan oleh menonjolnya rangsangan dan bujukan dari penutur atau penulis agar mitra tutur atau pembaca mengikuti apa yang diharapkan penutur atau penulis, seperti pada iklan. Berikutnya wacana hortatoris dicirikan oleh kuatnya amanat yang dikandung dalam bahasa, seperti pada khotbah keagamaan. Akhirnya wacana prosedural dicirikan oleh menonjolnya proses, langkah, maupun tahap, seperti pada buku petunjuk penggunaan alat (Kushartanti, 2009).

\section{Aspek Wacana}

Pada aspek wacana terdapat kohesi dan koherensi. Kohesi adalah keterpaduan struktur, sedangkan yang dimaksud dengan koherensi adalah keruntutan makna. Para ahli menyatakan bahwa kekacauan ditentukan oleh hubungan kohesinya. Hubungan kohesi terbentuk jika penafsiran suatu unsur dalam ujaran bergantung pada penafsiran makna ujaran yang lain, dalam arti bahwa yang satu tidak dapat ditafsirkan maknanya dengan efektif kecuali mengacu kepada unsur yang lain. Selain itu, jenis hubungan kohesi ditandai dengan hubungan sebab akibat yang terdiri dari yang bersifat mantiki, bersifat alami, pengalaman dan urutan waktu.

Selanjutnya hubungan antar kata yang secara garis besar hubungan ini dapat dibagi menjadi dua yaitu hubungan endofora, bila yang dirujuk oleh pronomina itu terdapat pada wacana, dan hubungan eksofora jika yang dirujuk oleh pronomina atau pembicara mengacu kepada sesuatu di luar wacana. Berikutnya yaitu pemarkahpemarkah yang terdiri dari pemarkah lanjutan dan pemarkah konjungsi. Yang terakhir yaitu pengulangan kata atau frasa yang terdiri dari hubungan ko-referensi dan hubungan kolokasi (Ahmad, 1998).

Selain kohesi terdapat juga koherensi. Koherensi adalah keutuhan makna-makna kalimat dalam wacana. Untuk menafsirkan wacana atau fragmen wacana tertentu diperlukan strategi untuk menentukan keruntutan wacana dengan beberapa aspek diantaranya asumsi koherensi, prinsip analogi, prinsip penafsiran lokal, ciri-ciri koordinat umum, keajegan struktur wacana, dan pengetahuan tentang dunia.

Wacana yang koherensif memiliki susunan bahasa yang teratur dan amanatnya saling menjalin satu sama lain dengan rapi. Keutuhan yang koherensif dijabarkan lewat hubungan semantis (makna) antarbagian, yang dapat diwujudkan melalui kohesi tetapi dapat juga tidak. Secara keseluruhan, hubungan makna yang koherensif menjadi bagian dari organisasi semantis (Arifin dkk., 2015). Beberapa kalimat dapat menjadi wacana jika kalimat itu memiliki hubungan makna yang koherensif.

\section{Kohesi}

Menurut Kushartanti, ada sesuatu yang menciptakan sebuah wacana (the property of being a text), yaitu keadaan unsur-unsur bahasa yang saling merujuk dan berkaitan secara sistematis. Keadaan unsur-unsur bahasa yang saling merujuk dan berkaitan secara sistematis itu disebut kohesi. Dengan adanya kohesi maka sebuah wacana akan menjadi padu, setiap bagian pembentuk wacana mengikat bagian yang lain secara mesra dan wajar. Kohesi tidak datang dengan sendirinya, tetapi diciptakan secara formal oleh alat bahasa, yang disebut sebagai pemarkah kohesi (cohesive marker), misalnya kata ganti 
(pronomina), kata tunjuk (demonstrativa), kata sambung (konjungsi) dan kata yang diulang (Kushartanti, 2009).

Adapun, kohesi dalam wacana diartikan sebagai kepaduan bentuk yang secara struktural membentuk ikatan sintaktikal. Wacana yang baik dan utuh mensyaratkan kalimat-kalimat yang kohesif. Sejalan dengan hal itu, kohesi wacana terbagi ke dalam dua aspek, yaitu kohesi gramatikal dan kohesi leksikal. Kohesi gramatikal antara lain adalah referensi, substitusi, elipsis, konjungsi sedangkan yang termasuk kohesi leksikal adalah sinonim, repetisi dan kolokasi.

\section{Kohesi Leksikal}

Kohesi leksikal menunjuk pada hubungan leksikal di antara bagian-bagian wacana untuk mendapatkan keserasian struktur secara kohesif. Kohesi leksikal dapat terjadi melalui pemilihan kata yang secara ketat dilakukan demi terjalinnya hubungan bentuk ataupun makna di antara suatu kata dengan kata lain yang sudah digunakan sebelumnya (Arifin dkk., 2015). Suatu bentuk teks dan wacana dikatakan bersifat kohesif apabila terdapat kesesuaian antara bentuk bahasa (language form) dengan konteksnya (situasi internal bahasa) (Arifin dkk., 2012). Kohesi leksikal dapat diwujudkan dengan reiterasi dan kolokasi. Reiterasi merupakan 'pengulangan kata-kata pada kalimat berikutnya untuk memberikan penekanan bahwa kata-kata tersebut merupakan fokus pembicaraan'. Reiterasi terbagi menjadi repetisi, sinonimi, hiponimi, metonimi dan antonimi.

\section{Kohesi Gramatikal}

Kohesi gramatikal merupakan 'hubungan semantis antarunsur yang dimarkahi alat gramatikal, alat bahasa yang digunakan yang kaitannya dengan tata bahasa'. Kohesi gramatikal dapat berwujud referensi atau pengacuan, substitusi atau penyulihan, elipsis atau pelesapan dan konjungsi atau penghubungan.

Senada dengan hal di atas, kohesi gramatikal tidak hanya ditunjukkan oleh hubungan internal antarunit dalam sebuah kalimat, tetapi juga antara kalimat sebelum ataupun sesudahnya dalam sebuah paragraf. Senada halnya dengan hubungan antara satu paragraf dengan paragraf sebelumnya dan sesudahnya dalam sebuah teks atau wacana (Zainurrahman, 2011).

\section{Hakikat Eksposisi}

Tulisan ekspositori atau eksposisi merupakan tulisan yang bersifat faktual. Tulisan eksposisi adalah tulisan yang memberikan informasi mengenai mengapa dan bagaimana, menjelaskan sebuah proses atau menjelaskan sebuah konsep. Selain itu, karangan eksposisi disebut juga dengan paragraf lukisan. Tujuannya adalah untuk menampilkan atau memaparkan sosok objek tertentu yang hendak dituliskan. Adapun fungsi sosial dalam eksposisi yaitu berusaha meyakinkan para pembacanya bahwa topik yang sedang disajikan merupakan sebuah topik bersifat "urgent" atau penting guna untuk sebuah diskusi maupun untuk menarik perhatian pembaca menggunakan cara seperti argumen maupun pendapat yang keduanya saling mendukung topik atau ide tulisan tersebut. Fungsi sosial eksposisi yang lainnya yaitu untuk mengajukan argumentasi bahwa sesuatu itu benar adanya (untuk eksposisi analitis) atau bahwa sesuatu yang diusulkan itu harus dilakukan (untuk eksposisi hortatoris).

Sejalan dari kedua fungsi sosial eksposisi yang telah dipaparkan di atas, fungsi sosial eksposisi yang lainnya yaitu eksposisi diposisikan sebagai teks ilmiah yang secara langsung berkontribusi dalam memperkaya wawasan pembaca. Hal tersebut juga 
diungkapkan (Sholehuddin, 2015) bahwa betapa pentingnya peran teks eksposisi dalam membangun kultur literasi ilmiah siswa dan tidak dapat dilepaskan dari karakteristik teks tersebut. Sifat ilmiah yang melekat pada teks mengakibatkan konsekuensi terhadap proses pembelajaran. dengan kemampuan bernalar (reasoning). Hal tersebut juga mengindikasikan bahwa pembelajaran sekaligus memiliki tujuan pengasahan keterampilan bernalar siswa. Selain itu, dalam tahap perumusan gagasan utama (tesis) dalam eksposisi juga diperlukan kemampuan merangkai sejumlah data dan fakta untuk kemudian disarikan dalam sebuah pernyataan umum. Atas dasar tersebut, menulis eksposisi menjadi penting untuk dikembangkan.

\section{Struktur Eksposisi}

Struktur dari eksposisi terdiri dari tesis, argumen dan penegasan ulang (Yustinah, 2014). Tesis berisi suatu pernyataan yang menunjukkan sudut pandang penulis terhadap persoalan atau isu tentang topik tertentu. Selanjutnya argumen, berisi sejumlah bukti atau alasan yang mendukung atau membuktikkan kebenaran tesis. Penegasan ulang yaitu merangkum atau menegaskan kembali sudut pandang dari penulis terhadap persoalan atau isu tentang topik tertentu.

\section{Kaidah Kebahasaan Eksposisi}

Dalam menulis ekpsosisi diperlukan sebuah kaidah bahasa untuk menunjang tatanan bahasa di dalam tulisan tersebut. Berkaitan dengan hal itu, kaidah kebahasaan yang terdapat pada teks eksposisi menurut Yustinah dibangun dari unsur-unsur yang meliputi.

1. Menggunakan nomina dan pronomina

Nomina merupakan kata benda dasar, seperti gambar, meja, rumah serta nomina turunan seperti pembelian, permaninan, kekebalan. Adapun pronomina merupakan kata yang dipakai untuk mengacu pada nomina lain seperti pronomina persona yang terdiri dari saya, engkau, dia, mereka dan pronomina penunjuk seperti ini, itu, sini, situ, serta pronomina penanya seperti apa, siapa, mana.

2. Menggunakan kata-kata leksikal verba, adjektiva dan adverbial.

Verba adalah kata kerja baik dari bentuk dasar seperti pergi, mandi, lukis maupun verba dari turunan seperti perjelas, perbaiki, mengalir. Adjektiva berupa kata keterangan seperti lekas-lekas, sesungguhnya.

3. Menggunkan kata hubung (konjungsi). Konjungsi yang sering digunakan misalnya lalu, sehingga, sambil, ketika, dan akhirnya.

4. Menyajikan argumentasi urut (lemah-kuat, sederhana-rumit atau sebaliknya).

5. Menyatakan sikap penulis (setuju atau tidak setuju) (Yustinah, 2014)

\section{Syarat Menulis Eksposisi}

Dalam menulis eksposisi, penulis perlu memperhatikan syarat agar tulisan eksposisi yang dibuat bisa terlihat baik. Seseorang yang ingin menulis sebuah eksposisi harus memenuhi syarat-syarat berikut ini. Pertama, penulis harus mengetahui serba sedikit tentang subjeknya. Dengan mengetahui serba sedikit tentang subjek yang akan ditulisnya, maka penulis dapat memperluas pengetahuannya mengenai hal itu, baik melalui penelitian lapangan, wawancara atau melalui penelitian kepustakaan.

Dari hasil penelitiannya itu dikumpulkan bahan sebanyak-banyaknya, dievaluasi, untuk kemudian ditampilkan dalam tulisannya tersebut. Syarat lain untuk menulis sebuah eksposisi yang baik adalah kemampuan untuk menganalisa persoalan tersebut secara jelas dan konkrit. Bahan yang dikumpulkan hanya merupakan bahan mati, bahan ramuan yang 
tidak berguna bagi tangan-tangan yang tidak ahli. Bahan yang dikumpulkan dengan berbagai cara di atas harus diolah, diseleksi, dievaluasi, dan dianalisa untuk dituangkan dalam sebuah karangan yang berbentuk final. Semakin baik evaluasi dan analisa yang dilakukan, maka akan semakin baik nilai eksposisi yang ditulisnya (Keraf, 1982).

\section{METODE PENELITIAN}

Penelitian ini menggunakan metode deskriptif kualitatif dengan teknik analisis isi, yaitu dengan menganalisis kesalahan kohesi serta faktor penyebab yang menjadi kesalahan tersebut. Metode deskriptif tersebut dilakukan dalam beberapa tahap, yakni tahap pengumpulan data, tahap analisis data, dan tahap penyajian data. Adapun penelitian ini dilaksanakan pada semester genap tahun pelajaran 2017/2018. Data penelitian, berupa karangan eksposisi siswa kelas $\mathrm{X}$ beserta kuisioner yang dibagikan ke siswa. Karangan eksposisi ini berjumlah 48 karangan. Wujud data yang diperoleh dalam penelitian ini adalah teks. Data-data tersebut didapatkan dari kuisioner yang dibagikan dan diisi oleh siswa serta menggabungkan hasil karangan eksposisi mereka. Dari karangan siswa yang terkumpul sebanyak 96 judul, maka dipilih 48 judul untuk dilakukan penelitian. Selain itu, digabungkan dengan hasil kuisioner yang telah mereka isi. Pengambilan data dilakukan dengan menggunakan teknik membaca kritis, secara cermat dan teliti. Teknik ini dilakukan untuk menemukan kesalahan serta mengetahui faktor penyebab dari kesalahan kohesi tersebut. Bersamaan dengan proses membaca kritis, dilakukan pula pengklasifikasian terhadap faktor penyebab yang didapatkan dari kuisioner, pengklasifikasian tersebut meliputi faktor penyebab dari segi kompetensi dan segi performansi.

\section{HASIL DAN PEMBAHASAN}

\section{Faktor Penyebab Kesalahan Kohesi Leksikal dan Gramatikal dalam Karangan Eksposisi Siswa.}

Kesalahan kohesi yang ditemukan di dalam karangan eksposisi siswa terlihat cukup signifikan. Jumlah kesalahan yang ditemukan bila dilihat dari jenis kohesinya terbagi menjadi dua yaitu kesalahan kohesi leksikal dan kohesi gramatikal.

Adapun untuk kesalahan kohesi leksikal dengan jumlah persentase kesalahan repetisi sebanyak 8 kesalahan $(3,31 \%)$, sinonimi sebanyak 2 kesalahan $(0.83 \%)$, hiponimi sebanyak 0 kesalahan $(0 \%)$, metonimi sebanyak 0 kesalahan $(0 \%)$, antonimi sebanyak 0 kesalahan (0 \%), kolokasi sebanyak 6 kesalahan $(1,71 \%)$. Berikut merupakan perbandingan dari kesalahan kohesi leksikal.

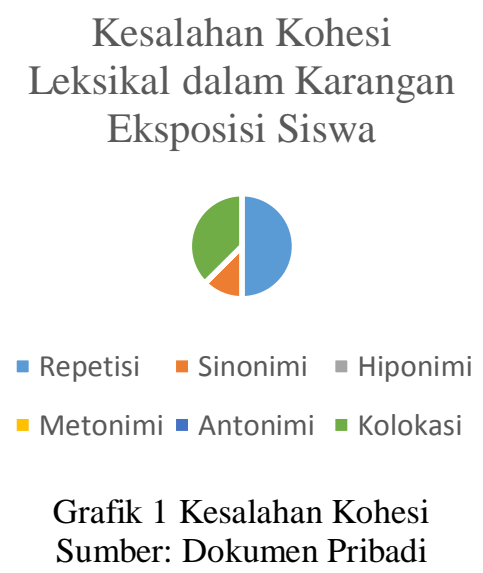


Berikutnya dari kesalahan kohesi gramatikal. Adapun kesalahan kohesi gramatikal dengan jumlah persentase kesalahan pada referensi sebanyak 29 kesalahan $(11,98 \%)$, substitusi sebanyak 2 kesalahan $(0.83 \%)$, elipsis sebanyak 15 kesalahan $(6,19$ $\%)$, dan relasi sebanyak 180 kesalahan $(74,38 \%)$. Berikut merupakan diagram dari hasil persentase kesalahan kohesi gramatikal.

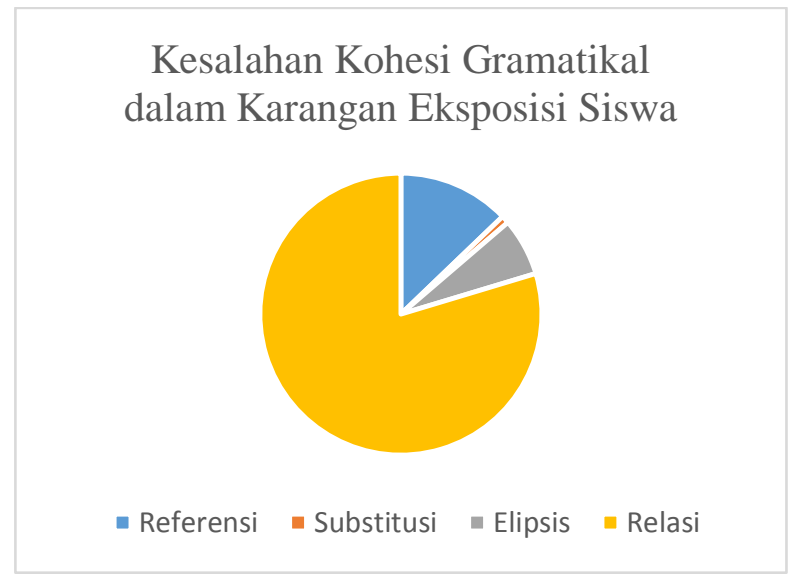

Grafik 2 Kesalahan Kohesi

Sumber: Dokumen Pribadi

Senada dengan uraian di atas, apabila digabungkan antara kesalahan kohesi leksikal dan gramatikal maka temuan paling banyak yaitu ditemukan pada kesalahan relasi, disusul dengan kesalahan referensi, elipsis, repetisi, kolokasi, sinonimi, substitusi, serta terakhir ditempati oleh hiponimi, metonimi, dan antonimi yang sama sekali tidak ditemukan kesalahan di dalam karangan siswa. Dari jumlah kesalahan tersebut terdapat beberapa faktor yang dapat mempengaruhi, diantaranya faktor performansi dan kompetensi. Faktor performansi merupakan bentuk kesalahan penampilan. Penampilan di sini bisa berupa sulit berkonsentrasi, letih, mengantuk, pusing, sulit mengingat materi, kurangnya media pembelajaran, cara guru ketika mengajar yang kurang tepat serta hal lainnya yang berkaitan dengan performansi.

Adapun faktor performansi yang banyak ditemukan adalah kurangnya konsentrasi siswa. Banyak siswa yang merasa sulit berkonsentrasi saat pembelajaran menulis karangan eksposisi. Hal tersebut terlihat pada saat mereka menulis, mereka tampak seperti kurang nyaman dan sering bertanya kepada temannya. Namun, hal tersebut biasanya juga bisa dipengaruhi oleh jam belajar bahasa Indonesia mereka yang berada di akhir jam pelajaran, sehingga mereka kehilangan semangat untuk mempelajari karangan eksposisi. Terlebih lagi saat mereka sedang tidak berkonsentrasi, maka mereka akan mengalami lesu, mengantuk dan pusing sehingga sangat menyulitkan mereka untuk memahami materi serta menulis karangan eksposisi.

Adapun faktor penyebab berikutnya yaitu dikarenakan sulit untuk mengingat materi, padahal guru telah menjelaskan disertai dengan diskusi kelas, namun karena keterbatasan siswa untuk mengingat materi sehingga apa yang telah disampaikan oleh guru menjadi tidak diserap dengan baik oleh siswa. Kesulitan mengingat materi ini nantinya berdampak pada saat siswa menulis karangan eksposisi, karena mereka tidak memahami bagaimana penulisan karangan yang berkohesi dan berkoherensi. Metode serta media yang digunakan oleh guru saat menjelaskan materi eksposisi juga sangat mempengaruhi daya ingat siswa. Berdasarkan hasil kuesioner, terlihat bahwa guru masih 
belum menggunakan media pembelajaran yang dapat membantu siswa untuk memahami materi eksposisi sehingga siswa menjadi jenuh ketika pembelajaran berlangsung dan menimbulkan banyak kekurangan dalam proses pembelajarannya. Begitu pun dengan diri mereka sendiri yang rata-rata sulit untuk menuangkan ide ke dalam tulisan, ditambah lagi dengan mereka yang tidak memiliki semangat untuk bertanya ataupun menjawab pertanyaan dari guru sehingga menjadikan pemahaman eksposisi mereka menjadi kurang.

Padahal jika antara guru dan siswa bisa saling melengkapi di dalam proses pembelajaran, maka kesalahan dalam karangan eksposisi bisa diminimalisir. Namun, selain faktor penyebab performansi, ternyata faktor kompetensi juga sangat mempengaruhi siswa. Diantara beberapa faktor kompetensi yang dapat mempengaruhi kesalahan kohesi dalam karangan siswa yaitu kurangnya pengetahuan siswa terhadap kaidah-kaidah di dalam bahasa sehingga siswa menjadi bingung dalam menerapkan kaidah yang benar di dalam karangan eksposisi. Sebagai contoh sederhananya adalah siswa masih belum bisa membedakan dan menerapkan relasi yang berada di dalam kalimat maupun antarkalimat sehingga banyak sekali ditemukan penggunaan relasi intrakalimat dan antarkalimat yang tidak tepat pada karangan yang mereka buat.

Faktor penyebab berikutnya yaitu siswa menyamaratakan kaidah bahasa yang sedang dipelajarinya sehingga menimbulkan kesalahan. Hal tersebut sebenarnya juga bisa terjadi karena ketidaktahuan akan batas-batas aturan suatu bahasa yang bisa saja guru belum menjelaskan secara menyeluruh terutama yang kaitannya dengan materi eksposisi. Sebagai contoh sederhananya adalah siswa menyamaratakan penggunaan relasi tetapi dan namun pada kalimat yang dibuat, padahal penggunaan tetapi dan namun tidak bisa disamaratakan penggunaannya meskipun sama-sama masuk ke dalam kategori relasi pertentangan.

Terakhir, faktor penyebab berikutnya yaitu karena adanya kesalahan konsep. Kesalahan konsep ini biasanya terjadi karena perbedaan bahasa yang sedang dipelajari. Sebagai contoh, di luar, siswa sedang mempelajari bahasa asing tetapi karena di sekolahnya diwajibkan berbahasa Indonesia maka secara tidak langsung konsep bahasa asing yang sedang dipelajarinya akan sedikit terbawa ke dalam penggunaan bahasa Indonesianya di sekolah. Bisa juga disebabkan karena perbedaan dalam menangkap penjelasan materi yang diberikan, terlebih lagi jika siswa tersebut mengikuti bimbingan belajar di luar sekolah, yang bisa saja terjadi perbedaan konsep antara di sekolah dengan bimbingan belajar yang mereka ikuti. Sebagai contoh perbedaan konsep sinonimi di sekolah dengan bimbingan belajar yang mereka ikuti di luar, di sekolah mereka diajarkan bahwa sinonimi merupakan persamaan kata sedangkan di tempat bimbingan belajar sinonimi merupakan persamaan makna. Jelas dari dua konsep ini saja sudah menimbulkan perbedaan konsep. Apabila dua perbedaan konsep ini tidak diluruskan, maka siswa akan merasa kebingungan saat mempraktikannya ke dalam karangan mereka

Dengan demikian, kesalahan kohesi leksikal dan gramatikal tidak serta merta terjadi begitu saja, melainkan dipengaruhi oleh beberapa faktor penyebab yaitu faktor performansi dan kompetensi. Kedua faktor tersebut saling mempengaruhi satu sama lain, seperti halnya peran siswa dan guru di dalam pembelajaran. Oleh karena itu, untuk mengurangi ataupun meminimalisir adanya kesalahan kohesi di dalam karangan eksposisi siswa, pihak guru dan siswa harus saling bekerja sama di dalam proses pembelajaran, terutama guru harus menciptakan metode serta media yang bervariasi di dalam proses pembelajaran berlangsung. 


\section{SIMPULAN}

Berdasarkan pembahasan di atas mengenai penyebab kesalahan kohesi leksikal dan gramatikal, maka dapat disimpulkan bahwa kesalahan berbahasa terjadi karena adanya faktor penyebab. Faktor penyebab tersebut meliputi faktor kompetensi dan performansi. Adapun dari segi performansi, faktor yang paling banyak ditemukan yaitu karena kurangnya konsentrasi siswa. Banyak siswa yang merasa sulit berkonsentrasi saat pembelajaran menulis karangan eksposisi dan sulit konsentrasi tersebut sebenarnya juga dipengaruhi oleh beberapa faktor lainnya. Adapun dari segi faktor kompetensi yaitu kurangnya pengetahuan siswa terhadap kaidah-kaidah di dalam bahasa sehingga siswa menjadi bingung dalam menerapkan kaidah yang benar di dalam karangan eksposisi. Oleh karena itu, untuk mengurangi ataupun meminimalisir adanya kesalahan kohesi di dalam karangan eksposisi siswa, pihak guru dan siswa harus saling bekerja sama di dalam proses pembelajaran, terutama guru harus menciptakan metode serta media yang bervariasi di dalam proses pembelajaran berlangsung.

\section{DAFTAR PUSTAKA}

Ahmad. (1998). Kapita selekta. Jakarta: IKIP Jakarta.

Arifin, E. Z., Junaiyah, H. M., Yulianto, E., Nurtriputro, I., Hilaliyah, H., \& Wiyanti, E. (2015). Wacana transaksional dan interaksional dalam bahasa Indonesia. Tangerang: PT Pustaka Mandiri.

Arifin, E. Z., Aswinarko, Sumadyo, B., \& Hilaliyah, H. (2012). Teori dan kajian wacana bahasa Indonesia. PT Pustaka Mandiri.

Azzahra, F. (2017, Oktober 16). Wawancara keterampilan menulis siswa. (Ria, Interviewer)

Bueraheng, R., Suyitno, I., \& Susanto, G. (2017). Kesalahan bentukan kata berafiks dalam karangan mahasiswa Thailand yang berbahasa ibu bahasa Melayu. Jurnal Pendidikan: Teori, Penelitian, dan Pengembangan, 2(6), 756-762.

Djajasudarma, F. (2006). Metode linguisitik: Bandung: PT Refita Aditama.

James, C. (1998). Errors in language learning and use: Exploring errors analysis. New York: Longman.

Keraf, G. (1982). Eksposisi dan deskripsi. Flores: Nusa Indah.

Kurniasari, A. H., Sumarwati, S., \& Ulya, C. (2017). Peranti kohesi gramatikal dan leksikal pada tulisan deskripsi siswa kelas VIII SMP dan relevansinya sebagai materi ajar bahasa Indonesia. Basastra, 4(1), 1-18.

Kushartanti. (2009). Pesona bahasa. Jakarta: PT Gramedia Pustaka Utama.

Moeliono, A. (2010). Tata bahasa baku bahasa Indonesia. Jakarta: PT Balai Pustaka. 
Palupi, D. (2013). Perbandingan kohesi dan koherensi dalam karangan deskriptif siswa kelas X SMK jurusan teknik otomotif kendaraan ringan (TOKR) dan rekayasa perangkat lunak (RPL) berdasar pada kemampuan berpikir analisis sintesis di bidang program keahlian. Seloka: Jurnal Pendidikan Bahasa dan Sastra Indonesia, 2(1).

Richard, J. C. (1974). Error analysis: Perspective on second language acquisition. London: Longman Group Limited.

Sholehhudin, M. (2015). Penerapan JIM (jurisprudential inqury model) pada pembelajaran keterampilan menulis teks eksposisi di kelas X SMAN MT Bojonegoro. Jurnal Pendidikan Edutama, 2(1), 21-38.

Wiyanti, E. (2016). Kajian kohesi gramatikal substitusi dan elipsis dalam novel Laskar Pelangi karya Andrea Hirata. Jurnal Pendidikan Bahasa dan Sastra UPI, 16(2), 188-202.

Sako, Y., Roekhan, R., \& Sunoto, S. (2017). Kesalahan berbahasa tataran sintaksis pada penulisan pengalaman pribadi siswa kelas X SMA. Jurnal Pendidikan: Teori, Penelitian, dan Pengembangan, 2(11), 1527-1533.

Tarigan, H. G., \& Tarigan, D. (1988). Pengajaran analisis kesalahan berbahasa. Bandung: Angkasa.

Yustinah. (2014). Produktif berbahasa Indonesia. Jakarta: Erlangga.

Zainurrahman. (2011). Menulis dari teori hingga praktik. Bandung: ALFABET. 